"Learning curve from the financial economic crisis of 2008 for organizations: a conceptual viewpoint"

$\begin{array}{ll} & \text { Shamil M. Valitov } \\ \text { AUTHORS } & \text { Almaz A. Nigmetzyanov } \\ & \text { Wilfred Isioma Ukpere } \\ & \text { Leona L. Grigoryeva }\end{array}$

Shamil M. Valitov, Almaz A. Nigmetzyanov, Wilfred Isioma Ukpere and Leona L. ARTICLE INFO Grigoryeva (2016). Learning curve from the financial economic crisis of 2008 for organizations: a conceptual viewpoint. Banks and Bank Systems, 11(2), 14-20. doi:10.21511/bbs.11(2).2016.02

DOI http://dx.doi.org/10.21511/bbs.11(2).2016.02

RELEASED ON Saturday, 02 July 2016

JOURNAL

"Banks and Bank Systems"

FOUNDER

LLC "Consulting Publishing Company "Business Perspectives"

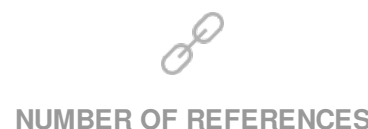

0

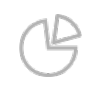

NUMBER OF FIGURES

0

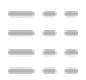

NUMBER OF TABLES

0

(c) The author(s) 2022. This publication is an open access article. 
Shamil M. Valitov (Russia), Almaz A. Nigmetzyanov (Russia), Wilfred Isioma Ukpere (South Africa), Leona L. Grigoryeva (Russia)

\title{
Learning curve from the financial economic crisis of 2008 for organizations: a conceptual viewpoint
}

\begin{abstract}
The objective of this paper is to critically analyze the concept of organizations considered as a too big to fail and how this phenomenon played out within the recent financial economic crisis of 2008. Special attention was paid to its negative characteristics and consequences. Nevertheless, these types of institutions seem to have become an inalienable part of the mo-dern financial world. The authors explored literatures on the relevant financial sector reforms by considering the experience of Switzerland and USA with regards to the Financial Stability Board. The authors suggest that financial economic crisis of 2008 revealed the necessity to carry out measures to prevent systemic risk caused by large financial organizations.
\end{abstract}

Keywords: financial organizations, financial institutions, financial market, world financial system, bankruptcy, bank regulators, systemic risk, default, moral hazard, credit and stock markets, financial regulation.

JEL Classification: G01.

\section{Introduction}

The conception "too big to fail" for financial organizations means that the role of these organizations is so significant that their bankruptcy will have catastrophic consequences for national economies. The largest financial institutions are the most important participants of the world financial market. Volume of their activity is so great that the problems in one of such companies and loss of control over them can destabilize the entire world financial system. Results of these companies' global activity can have a great impact on world economy. In other words, problem with any of the "too big to fail" institutions can cause difficulties in other financial organizations around the world and even undermine world economy. One of the latest examples of this case is the bankruptcy of such a financial giant as Lehman Brothers. Thus, the term "too big to fail" became widely used after the financial economic crisis of 2008, where by this term was referred to all negative things that had happened during the crisis (Fernholz, 2009). For example, King (2009) accentuated that institutions of private property, which are managed privately and became "too big to fail" occupy particular (strange) place in market economy. Thus, the problem "too big to fail" became the leading problem in the list of problems, which require solutions (Cho, 2009). In connection to this fact, Green, Mcllwain \& Scott (2010) define company as "too big to fail", when to prevent unacceptable political and economic

(c) Shamil M. Valitov, Arthur A. Nigmetzyanov, Wilfred Isioma Ukpere, Leona L. Grigoryeva, 2016.

Shamil M. Valitov, Kazan Federal University, Institute of Management, Economics and Finance, Russia.

Arthur A. Nigmetzyanov, Kazan Federal University, Institute of Management, Economics and Finance, Russia.

Wilfred Isioma Ukpere, Department of IPPM, Faculty of Management, University of Johannesburg (UJ), Auckland Park 2006, South Africa.

Leona L. Grigoryeva, Kazan Federal University, Institute of Language, Russia. risks, the government will decide to sacrifice the taxpayers' money to avoid this company's bankruptcy than to initiate the procedure of the given problem's solution through the bankruptcy.

\section{Objectives}

The objective of research paper was to critically analyze the "too big to fail" phenomenon paying special attention to its negative characteristics, and, at the same time, to establish why the given institutions are an inalienable part of the modern financial world. Furthermore, the aim of this paper was to analyze various criticisms and effects of the concept "too big to fail" on the global financial system, in order to propose possible solutions to correct the inadequacies of the practice.

\section{Scope of the research}

The research analyzed the financial economic crisis of 2008 , focusing on the concept "too big to fail" organizations. The research mainly explores the substantive and procedural aspects of the concept, its criticism and effects on the global financial system, in addition to issues of implementation and enforcement, with particular reference to Switzerland and the USA financial regulatory policies.

\section{Research methodology}

The literature relevant to a study of financial sector reform is fairly extensive. It covers ideas related to the benefits of the financial sector. In this research, the focus is on the literature related to financial sector reform and crisis. The research relies on both primary and secondary sources of information on the international financial and economic crises. The primary information was based on the researchers' observations and viewpoints. In terms of the secondary sources, references are taken from various background papers, books and scholarly articles. Various internet sites were consulted for relevant 
up-to-date information. Most importantly, the current information available on the research topic was imperative to keep track of the development within the area.

\section{Literature review}

The problem "too big to fail" is not a new one. As early as 1991, Hetzel related "too big to fail" to a practice which many bank regulators followed to protect major banks' creditors (insured, as well as uninsured, including liabilities holders) from losses in case of bankruptcy (Hetzel, 1991). Dymski (2011), as well as Hetzel (1991), considers the politics of "too big to fail" to be a consequence of administrative agencies' activity of protecting consumers (Davis, 1992). Thus, unlike Hetzel (1991), Dymski (2011) figures out that, at modern stage, the objective of this activity is to protect the stability of financial market (La Ware, 1991). Moreover, Dymski (2011) insists on the necessity to distinguish "too big to fail" as an intervention and as politics. As politics, "too big to fail" goes back to 1971, when Boston Unity Bank was bailed out by the decision of Federal Deposit Insurance Corporation (FDIC) (McCoy, Pavlov \& Watcher, 2009). Even then, worries that this decision, in a long-term perspective, can lead to more serious consequences than bankruptcy of just one bank were highlighted (Deregulation and Regulatory Failure, 2009). During financial economic crisis of 2008, the problem "too big to fail" newly appeared after controversial rescue of Bear Sterns and leaving Lehman Brothers unassisted, thereafter, G-7 countries took a decision to protect systemic important financial institutions (Saunders, Smith \& Walter, 2009). Thus, in order to clearly understand the phenomenon "too big to fail" and to fill previous research gap, it is essential to find balance between "systemic risk" and "moral hazard".

\section{Theoretical foundation}

5.1. Systemic risk. Systemic risk is the possibility of negative consequences of one market participants' default on others owing to their interdependency that can, in turn, lead to bankruptcy of not only financial organization, but also the entire financial market. In 1992, while analyzing financial situation in the world of 1970s and 1980s, Davis (1992) defined systemic risk as market disruptions which lead to unforeseen changes in prices in credit and bond markets, which lead to the bankruptcy of financial organizations (Kaufman, 2002). Thus, Davis (1992) noted the difference between "systemic risk" and the "turningpoints" of trade cycle. The latter is a normal stage of modern economic cycle. On the contrary, "financial crisis" is a macroeconomic depression and dysfunction of payment mechanism, which follow downfalls in the financial market (Labonte, 2013). In other words, the disruption in the function of financial in- termediaries leads to financial debacle on international level (Ali and Medhekar, 2013).

While financial market, in its essence, is a systemic market, its conception includes over the counter derivatives market, interbank market, stock market, mortgage market, public debt market and foreign exchange market. Therefore, some economists consider financial institutions' activity in financial markets to be apt to systemic risk (Wilmarth Jr, 2010). Thus, bank business is based on the use of short-term deposits in longterm investment programs and, therefore, when the market experiences instability, investors withdraw their investments. This fact, in turn, initiates spreading of panic and mass withdrawal of deposits. For example, La Ware (1991) figuratively compared systemic crash, caused by large financial institutions, with a catastrophe in the atomic station (Labonte, 2013). In these periods, banks encounter the problem of lack of liquidity which leads to decrease in solvency and bankruptcy.

Taking into account the fact that one bank is a depositary's debtor in another bank or other financial institutions' creditor, a chain or network is built. Failure of one of the links leads to the liquidity crisis in the chain or a network of financial institutions. For example, in 2008, during the financial crisis, the USA government decided to rescue AIG, Citigroup and Bank of America, by explaining that failure of one of these companies will have catastrophic consequences in the network of financial institutions around the world. Financial Stability Board associates systemic risk with losses in financial sector which exceed possible border. Experts in finances and economics consider such losses to be an indicator of systemic events, which are frequently characterized by deterioration of financial services provision and potentially harmful for the real economic sector, and which are particularly identified by losses of non-bank creditors instead of the banks and banks-partners' shareholders. In other words, not only do financial institutions have losses, but also organizations in other economic sectors, such as industrial and trading companies, since these organizations require financial transactions to run a business. Banks, in turn, are a key element in financial transactions. A bright example of dangerous influence of financial crisis on the real economic sector was described by Sorkin (2011) in a dialogue with the General Electric chairman and chief, Jeffry Immelt and the secretary of the USA Treasury, Henry M. Paulson, where Immelt complained of the difficulties in making current payments.

\section{Moral hazard}

Bankruptcy of any Systemic Important Financial Institution (SIFI) is unacceptable. Taking into account their importance for economic and financial system, such institutions have to be protected from 
collapse by the government. This protection gives birth to impunity and permissiveness, which can result in excessive risky way of conducting business and bring about decrease in market discipline in the process of profit-making (Ali, Islam, Nguen and Smith, 2015). This given phenomenon of behavioral change is known as "moral hazard". For example, Kaufman (2002) stated that, before the introduction of investment insurance system in 1934, large banks were not frequently insolvent and bankrupt. Related to financial and economic crisis of 2008, King (2009) proclaimed that the massive support given to the banking sector around the world resulted in the unprecedented "moral hazard" in history. In present time, the task to regulate SIFI has become urgent. According to Cassis (2011), financial crisis raised great necessity to change regulatory policy, and particularly, in cases, when consequences of large, complicated and interrelated international institutions' collapse may lead to the shake of financial system and confirmation of real sector, which was noticed during financial economic crisis of 2008. Relief operations obviously had serious consequences for the budget and tax payers, and, possibly, even for future generations. For instance, in time of crisis, Euro commission spent 3.6 trillions of Euro or $31 \%$ of GDP of EU as means to assist financial institutions. Moreover, moral hazard caused by government assistance and implied government guarantees can lead to the weakening of market discipline and distortion of competitiveness. Therefore, a question whether to rescue SIFI or not arises.

\section{To save or not to save}

During financial economic crisis of 2008, regulators used only opportunities of government support as means of financial shock prevention. Thus, the company or financial institution rescue is a wider conception. Labonte (2013) distinguishes bail-out and emergency government programs, which have different objectives. The first one is the government assistance to an individual company to rescue it from failure. In other words, it is assistance given to the company in stress to perform its duties and obligations. The second is to provide liquidity of a solvent company, i.e., crediting of ready assets, if they are paid back after the company's financial stabilization. Bovenzi, Guynn and Jackson (2013) distinguished rescue based on taxpayer-funded bailouts and by means of fire-sale liquidation. Difference between these means is that the first one is used at stage when assets are slow, but possess certain value. Furthermore, in case of absence of assistance at this stage, the panic occurs, which results in urgent sale of assets. In other words, the liquidity problem is transformed into the problem of solvency. In connection to this fact, to work out means of rescue, Bovenzi et al. (2013) stressed the necessity to distinguish capital and liquidity. For example, the first one is used by Ministry of Finances in the Troubled Asset Relief Program (TARP) and the second - by central banks as a last resort, which, unlike the Relief program, is only a temporary borrowing.

\section{To save}

In the current globalized world, systemic character of financial institution is a positive quality. For example, Calomiris (2009) stated that large sizes of financial institutions are more profitable, particularly for the clients, and not for the banks. Firstly, large banks are more suitable for international business. Secondly, the suggested products and services are cheaper in comparison with analogous products and services of smaller banks. And, finally, only large and interrelated financial institutions can provide means for arbitration operations among markets, which provide global integration in the market. Besides, Swagel (2011) marked out the advantages of large financial institutions for the market by pointing at more advantageous prices for the given companies. In the same way, advantages of large banks originate not from evident guarantees from the government, but from the management's scale. Thus, organization will be of systemic importance, if its viability can be decisive for reliable functioning of the financial system as a whole. This definition emphasizes positive contribution of similar organizations in social well-being. Therefore, large banks and other financial companies are the "spine" of financial system. In other words, financial stability is based on SIFI. In addition, Gennaioli et al. (2013) and Tarullo (2011) stated that SIFI were not an actual reason of financial economic crisis of 2008, and that the real reason was insufficient diversification of risks, since investment portfolios of financial organizations contained securities based on mortgage.

Modern understanding of macroeconomics results, in conclusion, believes that large financial organizations are more reliable in comparison with their smaller competitors. In the first place, there is a need for appropriate regulation level. Practically, recognition of an organization, as systemic important, signifies ability to borrow means at a lower price than smaller banks at 70 basic stations. This quality is particularly important during crisis. For the market participants, status of SIFI means that this organization is under enhanced attention by oversight bodies. This means that the given organization is more reliable. Therefore, this organization can attract investments from the developing countries with less stable economies, such as "safe harbor". As a result, investors from the developing countries provide prosperity of the developed ones, aware that foreign government will protect their 
investments. At the same time, the developing countries suffer from the money outflow. Therefore, bankruptcy of SIFI can significantly reduce the level of trust. As a result, the money flow will change its direction from the country - host of SIFI. Finally, financial prosperity of the past in the accepting country will become worse. This fact supposes that SIFI can and must rely on government support in a difficult situation.

\section{Not to save}

Nevertheless, the existing system of rescue generates threat of crisis repetition in connection with recklessness of systemic banks' politics, which confidently continue to rely on the government's help. For example, large banks were the reason for the last financial crisis, since they mostly financed unstable "bubbles". Thus, large financial institutions were the ones who received government support at the cost of ordinary tax-payers, small and medium businesses which, in turn, were left to their own fate. For example, more than $90 \%$ of government support was directed to 145 banks with assets of more than 100 billion dollars. Sorkin (2011) proved that particularly large companies used advantages of favorable regulatory regime, received great financial help and, as a result, were saved from bankruptcy. In the final report of forum on control of the means use within the financial support program in the USA Congress in 2011, it was mentioned that Troubled Asset Relief Program (TARP) intended for the US largest banks enhanced the problem of "too big to fail" organisation: the market is confident that systemic banks are safer than the ones which are too small to be helped. For this reason, small, in comparison to large banks, continue to overpay to borrow resources. It is admitted that, while protecting systemic banks from bankruptcy and failure, TARP also originated the problem of moral hazard and particularly by systemic important financial institutions.

On the contrary, small and medium businesses are responsible for all difficulties connected to the SIFI rescue. Thus, Stiglitz (2010) urged that there is a need to stop giving support to the banks and, as a result, to allow small banks to outlive collapse. Speaking in the USA Senate hearing, he stated that large-scale government support assisted in the financial system's rescue from the catastrophe, but this support contradicted the laws of capitalism, in accordance to which investors had to hold responsibility for their decisions. He also stressed that the system cannot be effective if it does not socialize losses and privatize profit. Moreover, Johnson and Kwak (2010) state that this type of politics undermines not only stability, but also belief in the entire political system's justice. For example, large banks were given significant gifts, whereas ordinary Americans had to solve problems on their own. Therefore, SIFI relief is not a correct decision. However, to allow them to reach bankruptcy is also not a solution to the problem. The given question cannot accept possibility of only two correct answers. There is a necessity to elaborate full and refined systems and mechanisms of regulation. However, specific regulation must be aimed at SIFI. From this, it follows that correct determination of SIFI will reduce systemic risk without increase of "moral hazard". In other words, this will be a step to the solution of the problem "too big to fail". Thus, there exists a problem of correct identification of SIFI.

\section{Identification of SIFI}

The question of SIFI identification is not accidental, since its influence on the world financial system stability is significantly high. Systemic important are large, closely interrelated with other organizations financial institutions, failure of which can lead to significant losses in economics. Companies and institutions considered to be systemic important are under enhanced supervision and control. Moreover, additional requirements to absorb losses are demanded from them. However, in present time, there exists no universal formula to identify SIFI. Precrisis financial regulation could not effectively prevent systemic risk, since SIFI were not properly defined. However, some authors do not support the idea of SIFI identification, since it enhances the problem of "moral hazard". On the contrary, Willmarth Jr (2010) states that the correct identification of SIFI is required for placing them under higher requirements and strict rules which, in turn, will lead to enhancement of market discipline by these organizations. Therefore, the correct classification is critically important for reduction of possibility of crisis occurrence in the future. Nevertheless, a set of systemic important functions, on the one hand, should not be too narrow for the protection from bank crisis' beginning, on the other hand. Too wide definition of these functions complicates anti-crisis management and reorganization of problematic institutions, which creates false stimuli to take decisions based on the market.

The easiest solution of initial identification of potential SIFI is to determine percentage of different indices of their activity: share in the entire volume of assets, clients' deposits, operations in interbank market, fond market, payment and calculation systems, since systemic importance, in the first place, depends on the size of the financial organization. However, Zhou (2010) stated that the size of the bank will be a one-sided approach to the identifica- 
tion of SIFI. Besides the assets' size as an index of systemic importance, for the banks, this can be sizes of interbank crediting, i.e., risk level generated for the other banks. Moreover, depositaries of securities, role of key participants in the foreign market of the main financial instruments can be used as a quantity index in the role of central con-tragent in the payment system. Thus, the organiza-tions should be considered as systemic important if they are closely interrelated and cannot abandon the market without serious disturbances of the market.

The main goal of SIFI identification is the reduction of systemic risk without enhancement of moral hazard. Inducement of financial institutions to make them smaller, for example, the reduction of international operations volume, can distort competitiveness in the market and enhance entire level of financial systemic risk. Therefore, it is important for all participants to understand that there are mechanisms which can rapidly and effectively reorganize the problematic SIFI. At the same time, this does not mean guaranteed purchase. Nevertheless, the fact is that financial organization recognition as SIFI can be a simple formality, since simplified classification based on threshold values, such as business scale, is announced by the market participants themselves. And, finally, banks can artificially maintain the required level of assets and not exceed the set limits aimed at not getting under limitations and enhanced control. An example can be the creation in the bank of a special purpose vehicle (SPV) structure for departure from regulation rules. SPV being legally independent from banks and their owners was used for highly risky activity; but, under conditions of crisis, they had to transform into the constitutive part of the bank balance and allowed the owner not to conceal debts, but use profits. For this reason, systemic importance of organization depends on how large is its ability to destruction. The larger the destructive potential, the higher is the danger of failure. Therefore, this index is the most important for the system.

It is important to consider sizes of losses not only for an individual bank, but also the whole system, which occur in other market segments and even in other regions. It is necessary to consider consequences for the real economic sector and fond bond market. Headquarters of many international SIFI are located in the leading countries of the world, and the remaining countries are regions of SIFI limited presence. At the same time, even in each small country, in addition to international, have their own national SIFI. However, the latter are present only at level of national economics. Therefore, systemic character is determined not only by the sizes of organization, but more by interrelations with other market participants. Nonetheless, recognition of an organization as systemic important should not lead to the unbearable burden of regulation and control when, additional limitations, control, and need for solutions make business environment of SIFI worse that in the end, can influence global state of the country's financial sector. Excessive worries about tyranny and helplessness of SIFI can negatively influence competitiveness of national economics. Furthermore, instead of financial stability, economics will become more uncertain. Thus, identification of SIFI should not lead to excessive strictness in its regulation. This extremeness can cause desire of financial organizations to become smaller and put limitations on transnational operations. Finally, the idea of universal criteria elaboration for identification of SIFI is based on the following: in different countries regulators, law makers, politicians and experts offer different, even opposite, formula regarding system making banks.

\section{Switzerland's experience}

At present, two Swiss banks are regarded as systemic important not solely in Switzerland, but also the world economics. Thus, the SIFI problem for Switzerland is highly up-to-date. In October 2010, in this country, the bases for SIFI regulation were founded. In April 2011, suggestions were introduced to the parliament. Taking into account recommendations of Basel Committee and Financial Stability Board (FSB), Swiss regulators are working under this policy realization on a national level. Resulted from the discussions with market participants, Swiss regulators determined the following list of system making functions: payment operations, deposits attraction in the internal market for the provision of access to liquid payment of resources, credits to nonfinancial organizations and mortgage credits in the national market with paying off terms of less than one year. So, considering question of financial institutions regulation, law makers take into account not only systemic important, but also other functions and, moreover, in addition to international character of financial transactions.

According to their opinion, organization is considered to be of systemic important if it provides services which are greatly important for economics as a whole, and they cannot be substituted by other market participants during a short period of time. At present, the Swiss initiative is concentrated on the banks. Mechanism of evaluation includes the following criteria: the market's share in the systemic important form of business running, such as deposits, credits, and clearings; the deposits' volume not covered by the system of investments insurance; correlation between the sizes of exchange balance and GDP; in addition to the organization's risk profile. Two Swiss banks: Credit Swiss Group and UBS were determined as systemic important on national and international levels.

\section{The USA experience}

Dodd-Frank law, which came into force in summer 2010, required identification of SIFI from the regu- 
lation bodies included into Financial Stability Oversight Committee (FSOC). According to Dodd-Frank law, SIFI are commercial bank groups with assets of 50 billion and more. Thus, the use of only one quantity index will be rather one-sided approach. As it was noted by American researchers Elliott and Litan (2011), identification of SIFI becomes complicated by volatility of systemic risk. In other words, it is impossible to exclude that organization, not determined as SIFI under conditions of unpredictable crisis development, will not behave as SIFI. Thus, bank groups with assets of 50 billion dollars and more do not exhaust SIFI spectrum in the USA. Systemic importance of a small bank can be displayed in some stressful situations. It is also necessary to take into account the availability of nonbank structures within the groups. Any bank can belong to financial, financial-industrial and financial-trading national or international group. It is known that crisis situation in the bank or another group's company can initiate chain reaction. In other words, fast problem spreading in the group can influence the financial sector as a whole or even the entire national economy. In this situation, there is no guarantee that head organization will give assistance to subsidiary company and not leave it to its own fate. Therefore, there exists a necessity of special regime of regulation for the banks in financial and financial-industrial-trading groups.

According to Elliott and Litan (2011), in the USA, systemic group importance is determined by existence of holding companies which, in formality, can or cannot be banks, but jointly can own a bank or banks. Therefore, according to Dodd-Frank law, a group connected with a commercial bank with assets not less than 50 billion dollars should automatically fall into SIFI category. In addition to the banks, SIFI category can include nonbank financial institutions. This can be insurance companies, associations, hedge funds and financial companies. These can also be institutions of financial market infrastructure, for example, stock markets and clearing companies. Nonetheless, the fact of recognition of an organization as systemic important can cause a threat of complacency and even inclination for the groundless risk with counting on government support in a difficult situation. The given politics can be accepted by large companies as an impetus to enlargement. For example, the last financial economic crisis was caused by the largest banks' strengthening. Therefore, this can lead to the opposite effect as desire to accept high risks and simultaneously have smaller responsibility for the business results. It is supposed that formal definition of SIFI can turn off vigilance of potentially important financial institutions, including banks, and create illusion that regulator was made ready to a new crisis. The same way, because of possible differences in SIFI classification in different segments of financial market, there is a threat of regulatory discretion. More precisely, a financial group can avoid limitations and enhanced requirements of external independent structures creation.

World financial crisis revealed insolvency of the existing system of global financial market regulation and became catalyst of national regulation system formation. One of the first organizations, which actively participated in solving this problem was Financial Stability Forum. This organization was approved by G-7. Later, in November 2008, taking into account global character of the last crisis, membership in the Forum was enlarged up to 20 countries (G-20), reestablished as a Financial Stability Board. Bank for International Settlements, in 2011, was the first one to publish the list of 29 so called SIFI which became a new official name of the one used before - previously, namely "too big to fail". The list included seven bank corporations in the USA, four of which are from France and Great Britain, three from Japan, two from both Germany and Switzerland, one from Belgium, China, Italy, Netherlands, Sweden and Spain.

SIFI are examined in context of four indices dependent on the gained points. Firstly, the following transnational operations: relations of transborder operations to overall profit, transnational obligations and rights of requirements related to overall sum of assets and liabilities. Secondly, relates to the sizes of gross and pure capital, and market capitalization. Thirdly, revolves around the possibility of financial institutions substitute; market share; full estimation of transactions and credit operations with securities; and gross turnover of over the counter derivative. Fourthly, entails the difficulty and confusion depending on the number of jurisdictions where operations are held. In November 2012, Financial Stability Board renewed its list and determined 28 financial institutions as "globally important systemic banks". In November 2013, one more Chinese bank (Industrial and Commercial Bank of China Limited) was added to this group. With this purpose, according to the method suggested by Bank Control Basel Committee, taking into account different indices, key of which became not the bank sizes, but the size of possible losses in case of the given organization failure.

\section{Conclusion and recommendations}

Taking into account the above analysis, it is possible to conclude that, long before the last crisis, systemic banks were leaders in spheres of mort- 
gage crediting boosting product and stock markets. The sudden abandoning of one or two market participants disrupted demand and supply balance and led to the failure of individual market segments, which caused serious turbulence in the stock market. In other words, instead of being a guarantor of stability, large banks became one of the main factors of economic instability. Therefore, it is reasonable to make recommendation that adequate politics would be an encouragement to reduction of systemic importance of large organizations. Nonetheless, it is necessary to provide survival of organizations considered important for the financial system. Thus, these two points of view are interrelated elements of the same phenomenon. It is evident that it is the market that has to determine SIFI as a positive or negative phenomenon and, as a result, whether it can survive or not.

\section{References}

1. Ali, M.M., Medhekar ,A. (2013). Role of financial intermediaries in creating international financial shock with special reference to Bangladesh: a critical review, Banks and Bank System, 8 (1), pp. 8-22.

2. Ali, M.M., Islam, A.M., Nguyen, C.V., Smith, J.G. (2015). Aftermath of the U.S. Subprime Mortgage Crisis of 20072009: A Comparison among USA, Bangladesh and Vietnam, World Review of Business Research, 5 (1), January 2015 Issue, pp. 39-57.

3. Bovenzi, J.F., Guynn, R.D., Jackson, T.H. (2013). Too Big to Fail: The Path to a Solution, A Report of the Failure Resolution Task Force of the Financial Regulatory Reform Initiative of the Bipartisan Policy Center (May 2013), p. 19.

4. Calomiris, Ch. (2009). In the World of Banks, Bigger Can Be Better, Wall Street Journal, Eastern Edition.

5. Cho, D. (2009). Banks “Too Big to Fail” Have Grown Even Bigger, The Washington Post, 28 August 2009.

6. Cassis, Y. (2011). Crises and Opportunities: The Shaping of Modern Finance. Oxford University Press 2011, p. 88.

7. Davis, E.P. (1992). Debt, Financial Fragility, and Systemic Risk. Oxford: Clarendon Press, p. 117.

8. Dymski, G.A. (2011). Genie out of the Bottle: The Evolution of Too-Big-to-Fail Policy and Banking Strategy in the US. Retrieved from: http://www.postkeynesian.net.

9. Elliot, D.J., Litan, R.E. (2011). Identifying and Regulating Systemically Important Financial Institutions: The Risks of under and over Identification and Regulation, Brookings Institution (January 16, 2011). Retrieved from: http://www.brookings.edu/research/papers/2011.

10. Fernholz, T. (2009). The Myth of Too Big to Fail: When it comes to banking, size isn't the only thing that matters, The American Prospect, 20 (9), p. 22.

11. Gennaioli, N., Shleifer, A., Vishny, R. (2013). A model of shadow banking, Forthcoming, Journal of Finance (08/2013), 68 (4), p. 1331.

12. Green, E.F., Mcllwain, K.L., Scott, J.T. (2010). A closer look at "too big to fail problem": national and international approaches to addressing the risks of large, interconnected financial institutions, Capital Markets Law Journal, 5 (2), pp. 117-118.

13. Hetzel, R.L. (1991). Too Big to Fail: Origins, Consequences, and Outlook, Economic Review, 3 (6), p. 3.

14. Johnson, S., Kwak, J. (2010). 13 Bankers: The Wall Street Takeover and the Next Financial Meltdown. New York: Panteon, 2010.

15. Kaufman, G. (2002). Too Big to Fail in Banking: What Remains? The Quarterly Review of Economic and Finance, 42, pp. 423-436.

16. King, M. (2009). Speech at the Lord Mayor's Banquet for Bankers and Merchants of the City of London at the Mansion House (17 June 2009) London.

17. Labonte, M. (2013). Systemically Important or "Too big to Fail" Financial Institutions. Congressional Research Service (June 19, 2013) 7-5700 R42150, pp. 8-10.

18. La Ware. (1991). Testimony Economic implications of the too big to fail policy: Hearing before the subcommittee on economic stabilization of committee on banking, finance and urban affair. U.S. House of Representatives, one hundred and second Congress, first session, May 9, p. 34.

19. McCoy, P.A., Pavlov, A.D. \& Watcher S.M. (2009). Systemic Risk through Securitization: The Result of Deregulation and Regulatory Failure. Conn.L.Rev, 41 (1327), pp. 1364-1366.

20. Saunders, A., Smith, R.C. \& Walter, I. (2009). Enhanced Regulation of Large, Complex Financial Institutions in V.V.Acharya and M.Richardson (Eds). Restoring Financial Stability: How to Repair a Failed System (NYU STERN 2009), pp. 144-145.

21. Sorkin, A.R. (2011). Too big to fail: The Inside Story of How Wall Street and Washington Fought to Save the Financial System and Themselves (Penguin 2011).

22. Stiglitz, J.E. (2010). Freefall: America, Free Markets, and Sinking of the World Economy (WW Norton 2010).

23. Swagel, Ph. (2011). Testimony on Enhanced Supervision: A new Regime for Regulating Large, Complex Financial Institutions Testimony on large complex financial institutions (December 7, 2011) Senate Banking Committee.

24. Tarullo, D. (2011). Regulating Systemic Risk. Credit Markets Symposium, Charlotte, North Carolina (March 31, 2011).

25. Wilmarth, Jr. A.E. (2010). Reforming Financial Regulation to Address the Too-Big-to-Fail problem, Brooklyn Journal of International Law, 35 (3), pp. 707-709.

26. Zhou, C. (2010). Are banks too big to fail? Measuring systemic importance of financial institutions, International Journal of Central Banking, 6 (4), p. 205. 